\title{
KOMBINASI METODE RULE-BASED DAN N-GRAM STEMMING UNTUK MENGENALI STEMMER BAHASA BALI
}

\author{
Made Agus Putra Subali ${ }^{1}$, Chastine Fatichah ${ }^{2}$ \\ 1,2 Departemen Informatika, Fakultas Teknologi Informasi dan Komunikasi, \\ Institut Teknologi Sepuluh Nopember, Surabaya \\ Email: ${ }^{1}$ madeagusputrasubali@gmail.com, ${ }^{2}$ chastine@if.its.ac.id
}

(Naskah masuk: 06 Oktober 2018, diterima untuk diterbitkan: 08 Januari 2019)

\begin{abstract}
Abstrak
Proses untuk mengekstraksi kata dasar dari kata berafiks dikenal dengan istilah stemming yang bertujuan meningkatkan recall dengan mereduksi variasi kata berafiks ke dalam bentuk kata dasarnya. Penelitian terdahulu tentang stemming bahasa Bali pernah dilakukan menggunakan metode rule-based, tapi afiks yang diluluhkan hanya prefiks dan sufiks, sedangkan variasi afiks lain tidak diluluhkan, seperti infiks, konfiks, simulfiks, dan kombinasi afiks. Penelitian tentang stemming menggunakan pendekatan rule-based telah diterapkan di berbagai bahasa yang berbeda. Metode rule-based memiliki kelebihan jika diterapkan pada domain yang sederhana, maka rule-based mudah untuk diverifikasi dan divalidasi, tapi memiliki kelemahan saat diterapkan pada domain dengan level kompleksitas yang tinggi, apabila sistem tidak dapat mengenali rules, maka tidak ada hasil yang diperoleh. Untuk mengatasi kelemahan stemming menggunakan rule-based, kami menggunakan metode $n$-gram stemming, dimana kata berafiks dan kata dasar diubah ke bentuk $n$-gram, kemudian tingkat kemiripan antara $n$ gram kata berafiks dan $n$-gram kata dasar diukur menggunakan metode dice coefficient, apabila tingkat kemiripannya memenuhi nilai ambang batas yang ditentukan, maka kata dasar yang dibandingkan dengan kata berafiks ditampilkan. Pada penelitian ini, kami mengembangkan metode stemmer yang meluluhkan seluruh variasi afiks pada bahasa Bali dengan mengombinasikan pendekatan rule-based dan metode $n$-gram stemming. Berdasarkan pengujian yang telah dilakukan untuk kesepuluh query metode yang diusulkan memperoleh rerata akurasi stemming lebih baik 96,67\% dari metode terdahulu $75 \%$, sedangkan untuk kelima query metode $n$-gram stemming dapat mengenali beberapa kata berafiks diluar rules. Penelitian berikutnya, kami akan memperhatikan semantik setiap kata dan tahap validasi menggunakan aplikasi text mining.
\end{abstract}

Kata kunci: stemmer bahasa Bali, rule-based stemming, n-gram stemming, dice coefficient.

\section{A COMBINATION OF METHODS RULE-BASED AND N-GRAM STEMMING TO RECOGNIZE BALINESE LANGUAGE STEMMER}

\begin{abstract}
A process for extracting a stem word from the inflected word is known as stemming which aims to increase recall by reducing the variation of the inflected word into its stem word form. Previous research on stemming the Balinese language has been done using the rule-based method, but the affixes that are removed are only prefixes and suffixes, while other variations of affixes are not removed, such as infixes, confixes, simulfiks, and combinations of affixes. Research on stemming using the rule-based approach has been applied in a variety of different languages. The rule-based method has advantages when applied to a simple field, rule-based is easy to verify and validate, but has weaknesses when applied to domains with a high level of complexity, if the system cannot recognize rules, no results are obtained. To overcome the stemming weaknesses using rule-based, we use the n-gram stemming method, where the inflected word and stem word are converted to the n-gram form, then the level of similarity between the n-gram of the inflected word and the stem word is measured using the dice coefficient method, when the level of similarity meets the defined threshold value, then the stem word is displayed. In this study, we developed a stemmer method that removes all variations of affixes in the Balinese language by combining the rule-based approach and the n-gram stemming method. Based on the experiments for the ten queries the proposed method get $96,67 \%$ stemming accuracy than the previous method $75 \%$, while for the five queries for the n-gram stemming method can recognize some inflected words outside the rules. The next study, we will pay attention to the semantics of each word and the validation stage using text mining application.
\end{abstract}

Keywords: Balinese language stemmer, rule-based stemming, n-gram stemming, dice coefficient. 


\section{PENDAHULUAN}

Bahasa Bali merupakan bahasa ibu bagi masyarakat etnis Bali memiliki kedudukan dan fungsi yang sangat penting. Komunikasi keseharian etnis Bali sering didominasi oleh pemakaian bahasa Bali, terutama dalam topik pembicaraan yang bersifat tradisional, seperti membahas masalah adat, kebudayaan, dan agama. Dalam bahasa Bali dikenal adanya kata dasar dan kata turunan. Kata turunan sering disebut dengan istilah kata berimbuhan. Istilah imbuhan dapat disejajarkan dengan afiks. Kata berafiks dalam bahasa Bali dapat dibedakan menurut tempatnya melekat pada bentuk dasar atau asal, yaitu prefiks, sufiks, infiks, konfiks, simulfiks, dan kombinasi afiks (Granoka dkk, 1996).

Proses untuk mengekstraksi kata dasar dari kata berafiks dikenal dengan istilah stemming (Balasankar dkk, 2016) yang bertujuan meningkatkan recall dengan mereduksi variasi kata berafiks ke dalam bentuk kata dasarnya (Patil \& Patil, 2017), (Pramudita dkk, 2018). Penelitian tentang stemming bahasa Bali pernah dilakukan oleh (Nata \& Yudiastra, 2017), pada penelitian tersebut, peneliti menggunakan metode rule-based dengan mengadopsi algoritma (Tala, 2003), tapi afiks yang diluluhkan hanya prefiks dan sufiks, sedangkan variasi afiks lain tidak diluluhkan, seperti infiks, konfiks, simulfiks, dan kombinasi afiks.

Metode rule-based merupakan metode yang menggunakan rules sebagai representasi pengetahuan untuk diimplementasikan ke dalam sistem (Ligeza, 2006), (Nikolopoulos, 1997), (Lindsay, 1988). Metode rule-based sangat bergantung pada penalaran manusia sebagai expert dalam memecahkan masalah. Pendekatan stemming menggunakan rule-based telah diterapkan di berbagai bahasa yang berbeda (Memet dkk, 2017). Bahasa Inggris, (Lovins, 1968), (Porter, 1980), (Porter, 2001), (Paice, 1994), (Krovetz, 1993). Bahasa Arab, (De-Roeck \& Al-Fares, 2000), (Larkey dkk, 2002). Bahasa Perancis, (Moulinier dkk, 2001). Bahasa Benggala, (Majumder dkk, 2007). Bahasa Turki, (Dincer \& Karaoglan, 2003). Bahasa Indonesia, (Nazief \& Adriani, 1996), (Adriani dkk, 2007).

Metode rule-based memiliki kelebihan jika diterapkan pada domain yang sederhana, maka rulebased mudah untuk diverifikasi dan divalidasi, tapi memiliki kelemahan pada saat diterapkan pada domain dengan level kompleksitas yang tinggi, apabila sistem rule-based tidak dapat mengenali rules, maka tidak ada hasil yang diperoleh (Grosan \& Abraham, 2011) dan pendekatan stemming menggunakan rule-based hanya spesifik terhadap bahasa yang digunakan (Mayfield \& McNamee, 2003). Untuk mengatasi kelemahan stemming menggunakan rule-based, kami menggunakan metode $n$-gram stemming yang dirancang oleh Adamson \& Boreham, pendekatan ini menunjukan bahwa kata yang memiliki kesamaan struktural lebih tinggi cenderung sama dengan artinya (Adamson \& Boreham, 1974), (Sembok \& Bakar, 2011), dimana kata berafiks dan kata dasar diubah ke bentuk $n$ gram, kemudian tingkat kemiripan antara $n$-gram kata berafiks dan $n$-gram kata dasar diukur menggunakan metode dice coefficient, apabila memenuhi nilai ambang batas yang ditentukan, maka kata dasar yang dibandingkan dengan kata berafiks ditampilkan.

Pada penelitian ini, kami mengembangkan metode stemmer yang meluluhkan seluruh variasi afiks pada bahasa Bali dengan mengombinasikan pendekatan rule-based dan metode $n$-gram stemming. Untuk membuktikan metode yang diusulkan dapat memberikan hasil akurasi stemming yang lebih optimal, kami melakukan serangkaian pengujian, seperti membandingkan hasil stemming metode yang diusulkan dengan metode terdahulu, dimana dari sepuluh query yang diberikan metode yang diusulkan memperoleh akurasi stemming lebih baik $96,67 \%$ dibandingkan metode terdahulu $75 \%$, menentukan nilai ambang batas yang paling sesuai pada seluruh variasi afiks, kisaran nilai ambang batas yang digunakan adalah 0,70, 0,65, dan 0,60, serta membandingkan beberapa variasi karakter $n$ gram pada metode $n$-gram stemming, yaitu $b i$-gram dan tri-gram.

\section{METODE PENELITIAN}

Penelitian ini terdiri dari beberapa tahapan antara lain studi literatur, penyusunan list kata dasar, perancangan sistem, serta hasil dan pembahasan.

\subsection{Penyusunan List Kata Dasar}

Sejumlah kata dasar bahasa Bali digunakan untuk memastikan bahwa hasil dari meluluhkan kata berafiks sesuai dengan bentuk dasarnya dan setiap kata dasar juga digunakan untuk dibandingkan dengan kata input pada metode $n$-gram stemming .

Penyusunan list kata dasar bahasa Bali diperoleh dari studi literatur pada buku dengan judul "Tata Bahasa Baku Bahasa Bali" dan artikel berita online bahasa Bali sejumlah lima puluh artikel dari situs https://balitv.tv/category/news/orti-bali selama bulan Nopember 2017, sejumlah kata berafiks yang diperoleh dari buku dan artikel berita bahasa Bali akan ditentukan bentuk kata dasarnya melalui penilaian yang diberikan oleh expert kemudian kata dasar disimpan dalam database. Kata dasar yang terkumpul sejumlah seribu kata dasar yang dapat diunduh melalui tautan http://bitly.com/2DWditK. Adapun tahapan mengumpulkan kata dasar dalam bahasa Bali dilakukan dalam Gambar 1. 


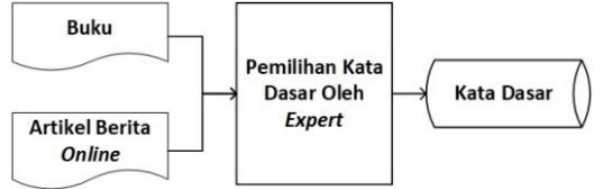

Gambar 1. Alur Proses Penyusunan List Kata Dasar

\subsection{Perancangan Sistem}

Pada penelitian ini, kami mengombinasikan metode rule-based dan $n$-gram stemming untuk stemmer bahasa Bali, dimana pada tahap awal dilakukan perbandingan apakah kata input merupakan kata dasar atau bukan dengan cara membandingkannya pada kamus kata dasar yang tersimpan pada database, apabila kata input merupakan kata dasar, maka kata dasar ditampilkan, apabila kata input bukan merupakan kata dasar, maka dilakukan proses meluluhkan afiks, dimulai dari meluluhkan prefiks, sufiks, infiks, konfiks, simulfiks, dan kombinasi afiks apabila rules yang tersedia tidak dapat mengenali kata input, maka untuk memperoleh kata dasar dilakukan proses string similarity menggunakan metode $n$-gram stemming, apabila tingkat kemiripannya memenuhi nilai ambang batas maka kata dasar ditampilkan. Adapun alur proses perancangan sistem dilakukan dalam Gambar 2, Gambar 3, dan Gambar 4.

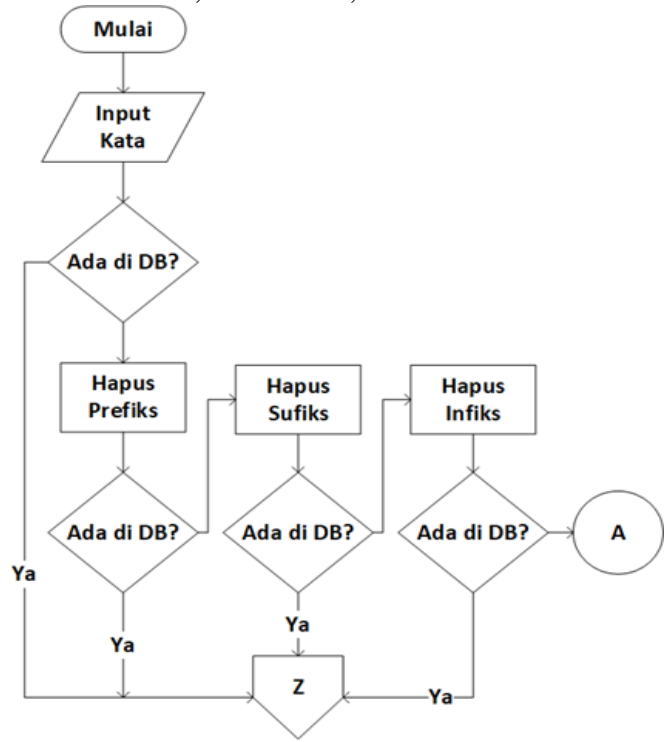

Gambar 2. Alur Proses Sistem Stemmer Bahasa Bali

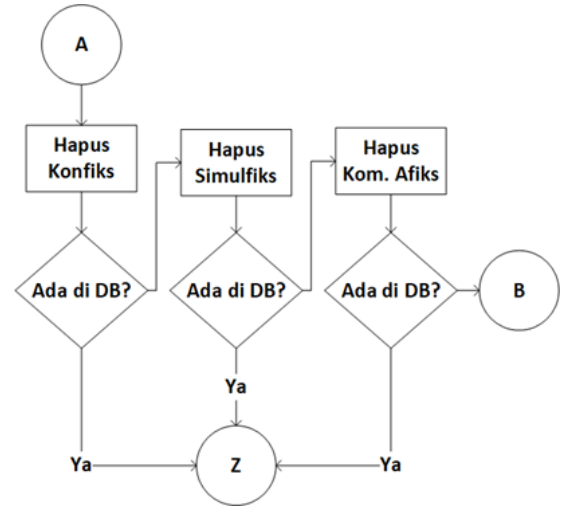

Gambar 3. On Page Connector A Stemmer Bahasa Bali

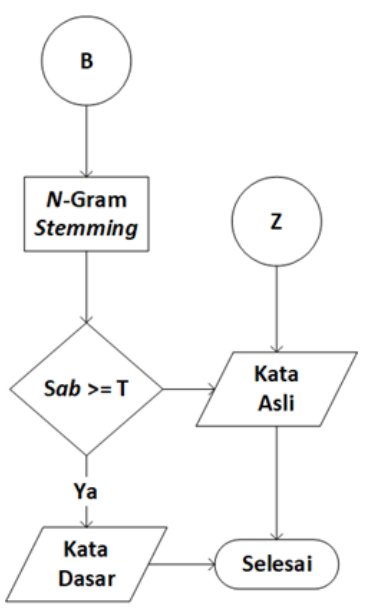

Gambar 4. Off Page Connector B Stemmer Bahasa Bali

\subsubsection{Hapus Prefiks}

Bahasa Bali memiliki dua belas bentuk prefiks, berikut merupakan rules atau aturan yang diterapkan untuk meluluhkan setiap prefiks pada bahasa Bali.

\subsubsection{Prefiks $n$}

Berikut adalah rules untuk proses meluluhkan prefiks $n$

1. Apabila bentuk dasarnya berawal dengan fonem vokal, maka untuk memperoleh bentuk dasar dilakukan penghapusan prefiks, contoh: ngidih bentuk dasarnya idih.

2. Apabila bentuk dasarnya berawal dengan fonem semivokal, maka untuk memperoleh bentuk dasar dilakukan penghapusan prefiks, contoh: ngwangun bentuk dasarnya wangun.

3. Apabila bentuk dasarnya berawal dengan fonem konsonan $t, d$, maka dibubuhkan alomorf $n$, untuk memperoleh bentuk dasar dilakukan pengubahan fonem $n$ menjadi $t$ atau $d$, contoh: negul bentuk dasarnya tegul dan nundun bentuk dasarnya dundun .

4. Apabila bentuk dasarnya berawal dengan fonem konsonan $c, j, s$, maka dibubuhkan alomorf ny, untuk memperoleh bentuk dasar dilakukan pengubahan fonem ny menjadi $c, j$, atau $s$, sebagai contoh: nyacad bentuk dasarnya cacad, nyaring bentuk dasarnya jaring, dan nyampat bentuk dasarnya sampat.

5. Apabila bentuk dasarnya berawal dengan fonem konsonan $k, g$, maka dibubuhkan alomorf $n g$, untuk memperoleh bentuk dasar dilakukan pengubahan fonem $n g$ menjadi $k$ atau $g$, sebagai contoh: ngutang bentuk dasarnya kutang dan ngambar bentuk dasarnya gambar.

6. Apabila bentuk dasarnya berawal dengan fonem konsonan $p, b$, maka dibubuhkan 
alomorf $m$, untuk memperoleh bentuk dasar dilakukan pengubahan fonem $m$ menjadi $p$ atau $b$, contoh: mapag bentuk dasarnya papag dan matek bentuk dasarnya batek.

7. Apabila bentuk dasarnya berawal dengan fonem konsonan nasal $m, n$, maka dibubuhkan alomorf nga, untuk memperoleh bentuk dasar dilakukan penghapusan fonem nga, contoh: ngamaling bentuk dasarnya maling dan nganengneng bentuk dasarnya nengneng.

\subsubsection{Prefiks $m a$}

Berikut adalah rules untuk proses meluluhkan prefiks $m a$ :

1. Apabila bentuk dasarnya berawal dengan fonem konsonan, maka untuk memperoleh bentuk dasar dilakukan penghapusan prefiks, contoh: makesiab bentuk dasarnya kesiab.

2. Apabila bentuk dasarnya berawal dengan fonem semivokal, maka untuk memperoleh bentuk dasar dilakukan penghapusan prefiks, contoh: mayasa bentuk dasarnya yasa.

3. Apabila bentuk dasarnya berawal dengan fonem vokal, maka untuk memperoleh bentuk dasar dilakukan penghapusan fonem $a$ pada prefiks ma, contoh: mikut kata dasarnya ikut dan mubad kata dasarnya ubad.

\subsubsection{Prefiks $p a$}

Aturan atau rules untuk proses meluluhkan prefiks $p a$ dilakukan apabila melekat pada bentuk asal yang dimulai dengan fonem vokal terjadi sandi, dalam hal ini fonem $a$ pada prefiks $p a$ diluluhkan. Contoh: pileh bentuk dasarnya ileh.

\subsubsection{Prefiks $k a$}

Aturan atau rules untuk proses meluluhkan prefiks $k a$ dilakukan apabila melekat pada bentuk asal yang dimulai dengan fonem vokal terjadi sandi, dalam hal ini fonem $a$ pada prefiks $k a$ diluluhkan. Contoh: kicen bentuk dasarnya icen.

\subsubsection{Prefiks sa}

Berikut adalah rules untuk proses meluluhkan prefiks sa:

1. Apabila bentuk dasarnya berawal dengan fonem konsonan, maka untuk memperoleh bentuk dasar dilakukan penghapusan prefiks, contoh: sajagat bentuk dasarnya jagat.

2. Apabila bentuk dasarnya berawal dengan fonem vokal, maka untuk memperoleh bentuk dasar dilakukan penghapusan prefiks, contoh: sausan bentuk dasarnya usan.

\subsubsection{Prefiks $a$}

Berikut adalah rules untuk proses meluluhkan prefiks $a$ :

1. Apabila bentuk dasarnya berawal dengan fonem konsonan, maka untuk memperoleh bentuk dasar dilakukan penghapusan prefiks, contoh: adiri bentuk dasarnya diri.

2. Apabila bentuk dasarnya berawal dengan fonem vokal, maka untuk memperoleh bentuk dasar dilakukan penghapusan prefiks, contoh: aukud bentuk dasarnya ukud.

\subsubsection{Prefiks pra}

Aturan atau rules untuk proses meluluhkan prefiks pra dilakukan apabila bentuk dasarnya berawal dengan fonem konsonan, contoh: prajani bentuk dasarnya jani.

\subsubsection{Prefiks pari}

Berikut adalah rules untuk proses meluluhkan prefiks pari:

1. Apabila bentuk dasarnya berawal dengan fonem konsonan, maka untuk memperoleh bentuk dasar dilakukan penghapusan prefiks, contoh: paribasa bentuk dasarnya basa.

2. Apabila bentuk dasarnya berawal dengan fonem vokal, maka untuk memperoleh bentuk dasar dilakukan penghapusan prefiks, contoh: pariindik bentuk dasarnya indik.

\subsubsection{Prefiks pati}

Aturan atau rules untuk proses meluluhkan prefiks pati dilakukan apabila bentuk dasarnya berawal dengan fonem konsonan, contoh: patigrape bentuk dasarnya grape.

\subsubsection{Prefiks maka}

Berikut adalah rules untuk proses meluluhkan prefiks maka:

1. Apabila bentuk dasarnya berawal dengan fonem konsonan, maka untuk memperoleh bentuk dasar dilakukan penghapusan prefiks, contoh: makasami bentuk dasarnya sami.

2. Apabila bentuk dasarnya berawal dengan fonem vokal, maka untuk memperoleh bentuk dasar dilakukan penghapusan prefiks, contoh: makaukud bentuk dasarnya ukud. 


\subsubsection{Prefiks saka}

Berikut adalah rules untuk proses meluluhkan prefiks saka:

1. Apabila bentuk dasarnya berawal dengan fonem konsonan, maka untuk memperoleh bentuk dasar dilakukan penghapusan prefiks, contoh: sakabesik bentuk dasarnya besik.

2. Apabila bentuk dasarnya berawal dengan fonem vokal, maka untuk memperoleh bentuk dasar dilakukan penghapusan prefiks, contoh: sakaukud bentuk dasarnya ukud.

\subsubsection{Prefiks kuma}

Aturan atau rules untuk proses meluluhkan prefiks kuma dilakukan apabila bentuk dasarnya berawal dengan fonem konsonan, contoh: kumajaum bentuk dasarnya jaum.

\subsubsection{Hapus Sufiks}

Bahasa Bali memiliki delapan bentuk sufiks, berikut merupakan rules atau aturan yang diterapkan untuk meluluhkan setiap sufiks pada bahasa Bali.

\subsubsection{Sufiks $a$} sufiks $a$ :

Berikut adalah rules untuk proses meluluhkan

1. Apabila bentuk dasarnya berakhiran dengan fonem konsonan, maka untuk memperoleh bentuk dasar dilakukan penghapusan sufiks, contoh: daara bentuk dasarnya daar.

2. Apabila bentuk dasarnya berakhiran dengan fonem vokal, maka dibubuhkan alomorf na, untuk memperoleh bentuk dasar dilakukan penghapusan fonem $n a$ pada sufiks $a$, contoh: anggona bentuk dasarnya anggo.

\subsubsection{Sufiks ang}

Berikut adalah rules untuk proses meluluhkan sufiks ang:

1. Apabila bentuk dasarnya berakhiran dengan fonem konsonan, maka untuk memperoleh bentuk dasar dilakukan penghapusan sufiks, contoh: jemakang bentuk dasarnya jemak.

2. Apabila bentuk dasarnya berakhiran dengan fonem vokal, maka dibubuhkan alomorf nang atau yang, untuk memperoleh bentuk dasar dilakukan penghapusan fonem nang atau yang pada sufiks ang, contoh: gedenang atau gedeyang bentuk dasarnya gede.

\subsubsection{Sufiks an} sufiks an:
1. Apabila bentuk dasarnya berakhiran dengan fonem konsonan, maka untuk memperoleh bentuk dasar dilakukan penghapusan sufiks, contoh: cenikan bentuk dasarnya cenik.

2. Apabila bentuk dasarnya berakhiran dengan fonem vokal, maka dibubuhkan alomorf nan, untuk memperoleh bentuk dasar dilakukan penghapusan fonem nan pada sufiks an, sebagai contoh: dawanan bentuk dasarnya dawa.

\subsubsection{Sufiks in}

Berikut adalah rules untuk proses meluluhkan sufiks in:

1. Apabila bentuk dasarnya berakhiran dengan fonem konsonan, maka untuk memperoleh bentuk dasar dilakukan penghapusan sufiks, contoh: jagurin bentuk dasarnya jagur.

2. Apabila bentuk dasarnya berakhiran dengan fonem vokal, maka dibubuhkan alomorf nin, untuk memperoleh bentuk dasar dilakukan penghapusan fonem nin pada sufiks in, sebagai contoh: jumunin bentuk dasarnya jumu.

\subsubsection{Sufiks $e$}

Berikut adalah rules untuk proses meluluhkan sufiks $e$ :

1. Apabila bentuk dasarnya berakhiran dengan fonem konsonan, maka untuk memperoleh bentuk dasar dilakukan penghapusan sufiks, contoh: payuke bentuk dasarnya payuk.

2. Apabila bentuk dasarnya berakhiran dengan fonem vokal, maka dibubuhkan alomorf $n e$, untuk memperoleh bentuk dasar dilakukan penghapusan fonem ne pada sufiks $e$, contoh: bajune bentuk dasarnya baju.

\subsubsection{Sufiks ne}

Berikut adalah rules untuk proses meluluhkan sufiks ne:

1. Apabila bentuk dasarnya berakhiran dengan fonem konsonan, maka untuk memperoleh bentuk dasar dilakukan penghapusan sufiks, contoh: baasne bentuk dasarnya baas.

2. Apabila bentuk dasarnya berakhiran dengan fonem vokal, maka dibubuhkan alomorf nne, untuk memperoleh bentuk dasar dilakukan penghapusan fonem nne pada sufiks $n e$, sebagai contoh: giginne bentuk dasarnya gigi.

\subsubsection{Sufiks $n$}

Aturan atau rules untuk proses meluluhkan sufiks $n$ dilakukan apabila bentuk dasarnya berakhiran dengan fonem vokal, contoh: bukun bentuk dasarnya $b u k u$. 


\subsubsection{Sufiks ing}

Aturan atau rules untuk proses meluluhkan sufiks ing dilakukan apabila bentuk dasarnya berakhiran dengan fonem vokal, contoh: rikalaning bentuk dasarnya rikala.

\subsubsection{Hapus Infiks}

Bahasa Bali memiliki empat bentuk infiks, berikut merupakan rules atau aturan yang diterapkan untuk meluluhkan setiap infiks pada bahasa Bali.

\subsubsection{Infiks in} infiks in:

Berikut adalah rules untuk proses meluluhkan

1. Apabila bentuk dasarnya diawali dengan fonem konsonan, maka infiks in disisipkan pada suku awal bentuk dasarnya diantara huruf konsonan pertama dan vokal yang mengikutinya, untuk memperoleh bentuk dasar dilakukan penghapusan infiks, contoh: sinurat bentuk dasarnya surat.

2. Apabila bentuk dasarnya diawali dengan fonem vokal, maka infiks in disisipkan di awal bentuk dasarnya, untuk memperoleh bentuk dasar dilakukan penghapusan infiks, sebagai contoh: inucap bentuk dasarnya ucap.

\subsubsection{Infiks um}

Berikut adalah rules untuk proses meluluhkan infiks um:

1. Apabila bentuk dasarnya diawali dengan fonem konsonan, maka infiks um disisipkan pada suku awal bentuk dasarnya diantara huruf konsonan pertama dan vokal yang mengikutinya, untuk memperoleh bentuk dasar dilakukan penghapusan infiks, contoh: rumaksa bentuk dasarnya raksa.

2. Apabila bentuk dasarnya diawali dengan fonem vokal, maka infiks um disisipkan di awal bentuk dasarnya, untuk memperoleh bentuk dasar dilakukan penghapusan infiks, sebagai contoh: umawak bentuk dasarnya awak.

\subsubsection{Infiks $e l$}

Aturan atau rules untuk proses meluluhkan infiks el dilakukan apabila bentuk dasarnya diawali dengan fonem konsonan, maka infiks el disisipkan pada suku awal bentuk dasarnya diantara huruf konsonan pertama dan vokal yang mengikutinya, untuk memperoleh bentuk dasar dilakukan penghapusan infiks, contoh: telapak bentuk dasarnya tapak.

\subsubsection{Infiks er}

Aturan atau rules untuk proses meluluhkan infiks er dilakukan apabila bentuk dasarnya diawali dengan fonem konsonan, maka infiks er disisipkan pada suku awal bentuk dasarnya diantara huruf konsonan pertama dan vokal yang mengikutinya, untuk memperoleh bentuk dasar dilakukan penghapusan infiks, contoh: gerudug bentuk dasarnya gudug.

\subsubsection{Hapus Konfiks}

Bahasa Bali memiliki empat bentuk konfiks, berikut merupakan rules atau aturan yang diterapkan untuk meluluhkan setiap konfiks pada bahasa Bali.

\subsubsection{Konfiks $p a$ - an}

Konfiks $p a$ - an dalam hal melekat pada bentuk dasar mengikuti kaidah prefiks $p a$ dan sufiks an, contoh: pasirepan bentuk dasarnya sirep.

\subsubsection{Konfiks $k a$ - an}

Konfiks $\mathrm{ka}$ - an dalam hal melekat pada bentuk dasar mengikuti kaidah prefiks $k a$ dan sufiks an, contoh: kasengsaraan bentuk dasarnya sengsara.

\subsubsection{Konfiks $m a$ - an}

Konfiks ma - an dalam hal melekat pada bentuk dasar mengikuti kaidah prefiks ma dan sufiks an, contoh: majemakan bentuk dasarnya jemak.

\subsubsection{Konfiks bra - an}

Konfiks bra - an dalam hal melekat pada bentuk dasar mengikuti kaidah prefiks bra dan sufiks an, contoh: bramahan bentuk dasarnya amah.

\subsubsection{Hapus Simulfiks}

Bahasa Bali memiliki dua bentuk simulfiks, berikut merupakan rules atau aturan yang diterapkan untuk meluluhkan setiap simulfiks pada bahasa Bali:

\subsubsection{Simulfiks $m a-n$}

Simulfiks $m a-n$ dalam hal melekat pada bentuk dasar mengikuti kaidah prefiks $m a$ dan diikuti prefiks $n$, contoh: mamuduh bentuk dasarnya buduh.

\subsubsection{Simulfiks $p a-n$}

Simulfiks $p a-n$ dalam hal melekat pada bentuk dasar mengikuti kaidah prefiks $p a$ dan diikuti prefiks $n$, contoh: pangalung bentuk dasarnya kalung.

\subsubsection{Hapus Kombinasi Afiks}

Bahasa Bali memiliki tiga bentuk kombinasi afiks, berikut merupakan rules yang diterapkan 
untuk meluluhkan setiap kombinasi afiks pada bahasa Bali.

\subsubsection{Kombinasi Afiks $m a$ - an}

Kombinasi afiks $m a$ - an dalam hal melekat pada bentuk dasar mengikuti kaidah prefiks ma dan diikuti sufiks an, sebagai contoh: makurenan bentuk dasarnya kuren.

\subsubsection{Kombinasi Afiks $m a$ - $n$ - in}

Kombinasi afiks $m a-n$ - in dalam hal melekat pada bentuk dasar mengikuti kaidah prefiks $m a$, prefiks $n$, dan diikuti sufiks in, contoh: manuturin bentuk dasarnya tutur.

\subsubsection{Kombinasi Afiks $m a$ - $\boldsymbol{n}$ - ang}

Kombinasi afiks ma - $n$ - ang dalam hal melekat pada bentuk dasar mengikuti kaidah prefiks $m a$, prefiks $n$, dan sufiks ang, contoh: mangorahang bentuk dasarnya orah.

\subsection{7. $N$ - Gram Stemming}

Apabila rules yang tersedia tidak dapat mengenali kata berafiks, maka dilakukan proses string similarity menggunakan metode $n$-gram stemming. Karakteristik kata berafiks yang tidak dapat dikenali oleh rules adalah adanya kesalahan dalam menuliskan kata berafiks, seperti kata maajalan, mejalan, mjalan. Adapun alur proses metode $n$-gram stemming dilakukan pada Gambar 5.

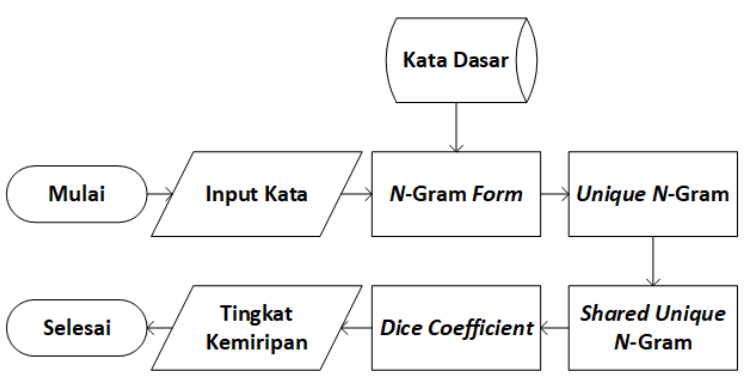

Gambar 5. Alur Proses N-Gram Stemming

Pada langkah pertama kata berafiks dan kata dasar pada database diubah ke bentuk n-gram kemudian dibandingkan dengan cara menghitung jumlah unique $n$-gram atau jumlah karakter $n$-gram yang dihasilkan dan shared unique $n$-gram atau jumlah karakter $n$-gram yang sama antara kata berafiks dan kata dasarnya. Tingkat kemiripan antara $n$-gram kata berafiks dan $n$-gram kata dasar diukur menggunakan metode dice coefficient mengikuti persamaan (1).

$d c=(2 \cdot c) \div(a+b)$

Pada persamaan (1), $d c$ merupakan dice coefficient. $c$ merupakan shared unique n-gram antara dua kata, sedangkan $a$ dan $b$ merupakan unique $n$-gram. Adapun tahap mengukur tingkat kemiripan antara dua kata majalan dan jalan menggunakan $n$-gram stemming, dengan jumlah karakter $n$ dua atau bi-gram dan tiga atau tri-gram dilakukan dalam Tabel 1.

\subsubsection{Menentukan Nilai Ambang Batas}

Ketika hasil perhitungan $n$-gram stemming antara kata input dan kata dasar memenuhi nilai ambang batas maka kata dasar ditampilkan. Kisaran nilai ambang batas yang digunakan adalah 0,70, 0,65 (Sembok \& Bakar, 2011), dan 0,60 (Adamson \& Boreham, 1974).

\subsubsection{Menghitung Akurasi Stemming}

Untuk menghitung hasil akurasi stemming kami menggunakan persamaan (2) (Husain, 2012).

$s=\frac{t}{n} \times 100$

Pada persamaan (2), s merupakan akurasi stemming. $t$ merupakan jumlah kata yang di stemming dengan benar. $n$ merupakan jumlah kata berafiks.

\section{HASIL DAN PEMBAHASAN}

Untuk membuktikan metode yang diusulkan dapat bekerja secara optimal, kami melakukan serangkaian pengujian, seperti membandingkan hasil stemming metode yang diusulkan dengan metode terdahulu, menentukan nilai ambang batas yang paling sesuai pada seluruh variasi afiks, dan membandingkan beberapa variasi karakter $n$-gram pada metode $n$-gram stemming .

Implementasi serta pengujian sistem dilakukan pada lingkungan pengembangan perangkat lunak sebagai berikut: OS Windows 10 Education 64-bit, Prosesor AMD A12-9720P, RAM 8,00GB, IDE Microsoft Visual Studio Enterprise 2017, Bahasa PYTHON 3.6 dengan Packages NLTK 3.3.

Data yang digunakan adalah 1000 list kata dasar yang dikumpulkan dari sejumlah dokumen buku dan artikel berita online berbahasa Bali. Sedangkan pada tahap pengujian kami menggunakan 15 query. Adapun kelima belas query yang digunakan terdapat pada Tabel 2, dimana pada baris kesebelas hingga kelima belas merupakan query yang digunakan untuk menguji metode $n$-gram stemming, dimana terdapat beberapa kata berafiks yang tidak dikenali oleh sistem rule-based, seperti kata berafiks yang ditulis salah serta adanya kata yang mengalami proses disimilasi.

Hal yang melatarbelakangi penggunaan metode $n$-gram stemming adalah kata yang memiliki kesamaan struktural lebih tinggi cenderung sama dengan artinya (Adamson \& Boreham, 1974), (Sembok \& Bakar, 2011). Namun akurasi stemming menggunakan pendekatan statistik tergantung 
dengan data training yang digunakan (Alotaibi \& Gupta, 2018).

$\underline{\text { Tabel 1. Mengukur Kemiripan Kata dengan } N \text {-Gram Stemming }}$

\begin{tabular}{|c|c|c|}
\hline & Bi-Gram & Tri-Gram \\
\hline majalan & $\begin{array}{c}\text { *m, } m a, a j, j a, a l, \\
\text { la, an, } n^{*}\end{array}$ & $\begin{array}{l}* * m, * m a, m a j, a j a, \\
\text { jal, ala, lan, an*, } n \text { ** }\end{array}$ \\
\hline jalan & $\begin{array}{c}* j, j a, a l, l a \\
\text { an, } n^{*}\end{array}$ & $\begin{array}{c}* * j, *_{j a}^{*}, j a l, \text { ala, lan, } \\
a n^{*}, n * *\end{array}$ \\
\hline$a$ & 8 & 9 \\
\hline$b$ & 6 & 7 \\
\hline$c$ & 5 & 5 \\
\hline$d c$ & 0,71 & 0,62 \\
\hline
\end{tabular}

Tabel 2. Daftar Query Pengujian

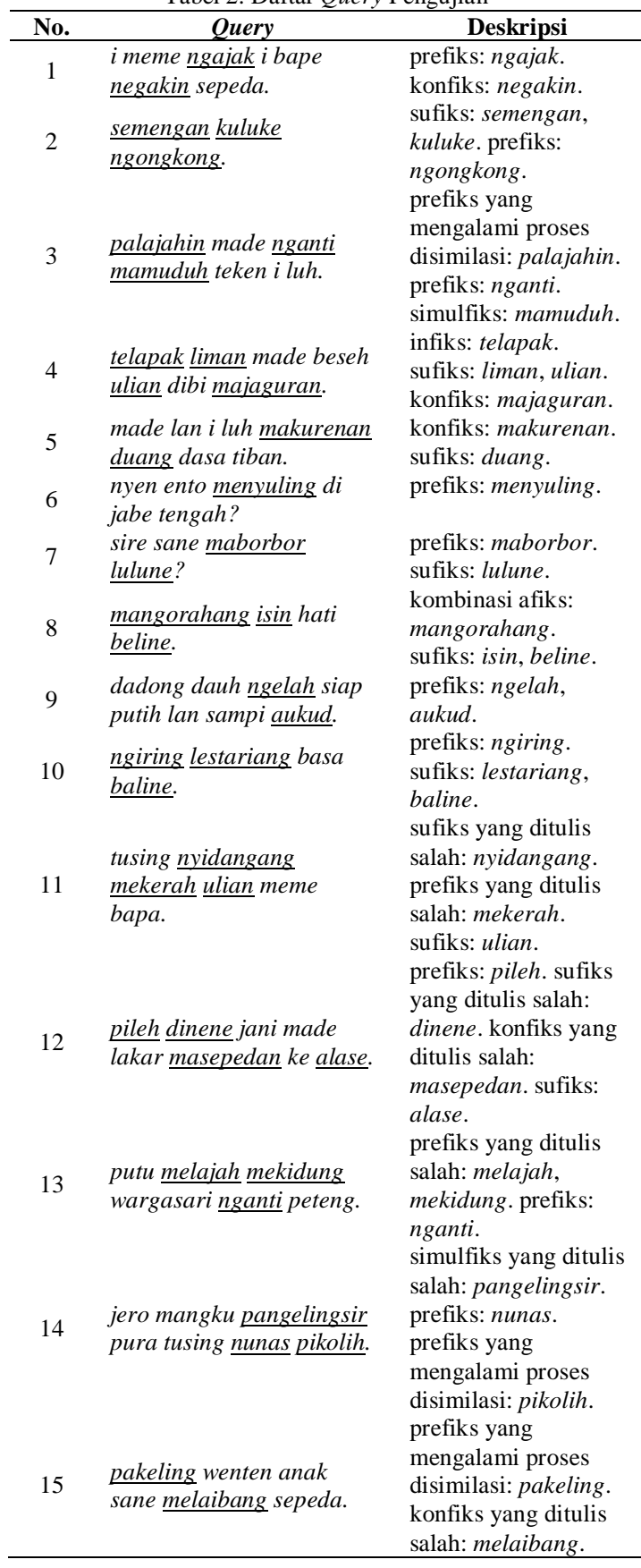

Berdasarkan hasil pengujian akurasi stemming untuk query satu hingga sepuluh yang dihitung menggunakan persamaan (2) terlihat pada Tabel 3, dimana metode yang diusulkan memberikan hasil stemming yang lebih baik dibandingkan metode terdahulu, hal ini dikarenakan pada penelitian Nata \& Yudiastra hanya meluluhkan dua variasi afiks, yaitu prefiks dan sufiks, kata berafiks seperti negakin, mamuduh, majaguran, dan kata berafiks lain terutama selain prefiks dan sufiks tidak dapat di stemming dengan benar.

Sedangkan hasil pengujian untuk query sebelas hingga lima belas menggunakan metode $n$-gram stemming antara dua variasi karakter $n$-gram, yaitu bi-gram dan tri-gram dengan kisaran nilai ambang batas $0,6,0,65$, dan 0,70 terlihat pada Tabel 4 hingga Tabel 6 akurasi stemming pada setiap kisaran nilai ambang batas, akurasi bi-gram lebih baik dibandingkan tri-gram, hal ini dikarenakan pada metode $n$-gram stemming jumlah unique $n$-gram pada $b i$-gram lebih sedikit dibandingkan tri-gram, sedangkan untuk jumlah shared unique $n$-gram pada bi-gram dan tri-gram bernilai sama, sehingga akurasi stemming dengan bi-gram memberikan hasil yang lebih baik.

Pada penelitian terdahulu yang dilakukan oleh Adamson \& Boreham menyebutkan untuk jumlah $n$ dua atau $b i$-gram memberikan beberapa informasi tentang urutan huruf dalam satu kata, sedangkan untuk jumlah $n$ tiga atau tri-gram memberikan lebih banyak informasi tentang urutan huruf, namun dapat menutupi terjadinya urutan karakter yang lebih pendek yang mungkin signifikan. Selain digunakan untuk memprediksi karakter berikutnya dalam urutan $n$ (Putra dkk, 2018), pemanfaatan $n$-gram sering digunakan untuk membangun kamus kata dari data training (Abidin \& Ferdhiana, 2016), (Mathew \& Bai, 2016).

Akurasi stemming pada setiap kisaran nilai ambang batas pada query kesebelas hingga kelima belas memperlihatkan semakin tinggi kisaran nilai ambang batas maka akurasi stemming akan semakin rendah, hal ini dikarenakan perbedaan urutan huruf antara kata yang dibandingkan akan mempengaruhi akurasi stemming, sebagai contoh kata berafiks bukun dibandingkan dengan kata dasarnya buku, dengan bi-gram memperoleh hasil 0, 72, padahal perbedaan antara kata bukun dan buku hanya terletak di satu urutan huruf pada sufiks $n$.

\begin{tabular}{clrr}
\multicolumn{5}{c}{ Tabel 3. Hasil Pengujian Query 1 - 10 } \\
\hline No. & Query & Nata \& Yudiastra \% & Metode Usulan \% \\
\hline 1 & Q1 & 50 & 100 \\
2 & Q2 & 100 & 100 \\
3 & Q3 & 33,33 & 66,67 \\
4 & Q4 & 50 & 100 \\
5 & Q5 & 50 & 100 \\
6 & Q6 & 100 & 100 \\
7 & Q7 & 100 & 100 \\
8 & Q8 & 66,67 & 100 \\
9 & Q9 & 100 & 100 \\
10 & Q10 & 100 & 100 \\
\hline \multicolumn{4}{c}{ Average }
\end{tabular}


Tabel 4. Hasil Pengujian N-Gram Stemming Query 11 - 15 dengan Nilai Ambang Batasa 0,60

\begin{tabular}{|c|c|c|c|}
\hline \multirow[b]{2}{*}{ No. } & \multirow[b]{2}{*}{ Query } & \multicolumn{2}{|c|}{ Akurasi } \\
\hline & & bi-gram \% & $\underset{\%}{t r i \text {-gram }}$ \\
\hline 1 & Q11 & 100 & 33,33 \\
\hline 2 & Q12 & 50 & 50 \\
\hline 3 & Q13 & 100 & 66,67 \\
\hline 4 & Q14 & 100 & 66,67 \\
\hline 5 & Q15 & 50 & 0 \\
\hline \multicolumn{2}{|c|}{ Average } & 80 & 43,33 \\
\hline
\end{tabular}

Tabel 5. Hasil Pengujian N- Gram Stemming Query 11 - 15 dengan Nilai Ambang Batas 0,65

\begin{tabular}{rlrr}
\hline \multirow{2}{*}{ No. } & \multirow{2}{*}{ Query } & \multicolumn{2}{c}{ Akurasi } \\
\cline { 3 - 4 } & & bi-gram \% & tri-gram \% \\
\hline 1 & Q11 & 33,33 & 0 \\
2 & Q12 & 50 & 25 \\
3 & Q13 & 66,67 & 66,67 \\
4 & Q14 & 66,67 & 33,33 \\
5 & Q15 & 50 & 0 \\
\hline \multicolumn{2}{c}{ Average } & $\mathbf{5 3 , 3 3}$ & $\mathbf{2 5}$
\end{tabular}

Tabel 6. Hasil Pengujian N- Gram Stemming Query 11 - 15

\begin{tabular}{ccrr}
\multicolumn{4}{c}{ dengan Nilai Ambang Batas 0,70 } \\
\cline { 3 - 4 } No. & \multirow{2}{*}{ Query } & \multicolumn{2}{c}{ Akurasi } \\
\cline { 3 - 4 } & & bi-gram \% & tri-gram \% \\
\hline 1 & Q11 & 33,33 & 0 \\
2 & Q12 & 50 & 25 \\
3 & Q13 & 66,67 & 33,33 \\
4 & Q14 & 33,33 & 33,33 \\
5 & Q15 & 0 & 0 \\
\hline \multicolumn{2}{c}{ Average } & $\mathbf{3 6 , 6 7}$ & $\mathbf{1 8 , 3 3}$ \\
\hline
\end{tabular}

\section{KESIMPULAN}

Pada penelitian ini, kami mengombinasikan metode rule-based dan $n$-gram stemming. Metode rule-based digunakan untuk membentuk rules yang meluluhkan seluruh variasi afiks sedangkan metode $n$-gram stemming digunakan apabila rules yang tersedia tidak dapat dikenali. Berdasarkan 1000 list kata dasar dan kesepuluh query yang diberikan antara metode yang diusulkan dan metode terdahulu, metode yang diusulkan memperoleh akurasi stemming lebih baik 96,67\% dibandingkan metode Nata \& Yudiastra 75\%, hal ini dikarenakan rules pada metode Nata \& Yudiastra hanya meluluhkan dua variasi afiks, yaitu prefiks dan sufiks, sedangkan pada lima query yang diberikan untuk n-gram stemming, kata berafiks yang tidak dikenali oleh rules dapat di stemming dengan baik, terutama pada bi-gram dengan nilai ambang batas 0,60.

Hasil pengujian menunjukan metode yang diusulkan memperoleh akurasi stemming lebih baik dari metode Nata \& Yudiastra serta metode $n$-gram stemming mampu mengenali beberapa kata berafiks yang tidak dapat dikenali oleh rules. Pada penelitian berikutnya, kami akan memperhatikan semantik setiap kata dan tahap validasi menggunakan aplikasi text mining tentang bahasa Bali (Putra dkk, 2016), yaitu question answering system.

\section{DAFTAR PUSTAKA}

ABIDIN, T.F. \& FERDHIANA, R., 2016. Algorithm for Updating N-Grams Word Dictionary for Web Classification. International Conference on Informatics and Computing (ICIC).

ADAMSON, G.W. \& BOREHAM, J., 1974. The Use of An Association Measure Based on Character Structure to Identify Semantically Related Pairs of Words and Document Titles. Information Storage and Retrieval, vol.10, pp.253-260.

ADRIANI, M., ASIAN, J., NAZIEF, B., TAHAGHOGHI, S.M.M. \& WILLIAMS, H.E., 2007. Stemming Indonesian: A Confix Stripping Approach. ACM Transactions on Asian Language Information Processing (TALIP).

ALOTAIBI, F.S. \& GUPTA, V., 2018. A Cognitive Inspired Unsupervised LanguageIndependent Text Stemmer for Information Retrieval. Cognitive Systems Research, vol.52, pp.291-300.

BALASANKAR, C., SOBHA, T. \& MANUSANKAR, C., 2016. Multi Level Inflection Handling Stemmer using Iterative Suffix Stripping for Malayalam Language. International Conference on Advances in Computing, Communications and Informatics (ICACCI), pp.530-534.

DE-ROECK, A.N. \& AL-FARES, W., 2000. A Morphologically Sensitive Clustering Algorithm for Identifying Arabic Roots. Proceedings of the 38th Annual Meeting on Association for Computational Linguistics, pp.199-206.

DINCER, B.T. \& KARAOGLAN, B., 2003. Stemming in Agglutinative Languages: A Probabilistic Stemmer for Turkish. International Symposium on Computer and Information Sciences (ISCIS), pp.244-251.

GRANOKA, I.W.O., NARYANA, I.B.U., JENDERA, I.W., BAWA, I.W., MEDERA, I.N., PUTRAYASA, I.G.N., ANOM, I.G.K., TAMA, I.W., DENES, I.M., PURWA, I.M., SUKAYANA, I.N., \& INDRA, I.B.K.M., 1996. Tata Bahasa Baku Bahasa Bali. Balai Penelitian Bahasa Pusat Pembinaan dan Pengembangan Bahasa Departemen Pendidikan dan Kebudayaan, Denpasar.

GROSAN, C. \& ABRAHAM, A., 2011. Rule-Based Expert Systems. In: Intelligent Systems, Intelligent Systems Reference Library, vol.17, pp.655-696.

HUSAIN, M.S., 2012. An Unsupervised Approach to Develop Stemmer. International Journal on Natural Language Computing (IJNLC), 
vol.1, pp.15-23.

KROVETZ, R., 1993. Viewing Morphology as An Inference Process. Proceedings of the 16th Annual International ACM SIGIR Conference on Research and Development in Information Retrieval, pp.191-202.

LARKEY, L.S., BALLESTEROS, L. \& CONNELL, M.E., 2002. Improving Stemming for Arabic Information Retrieval: Light Stemming and Co-Occurrence Analysis. Proceedings of the 25th Annual International ACM SIGIR Conference on Research and Development in Information Retrieval, pp.275-282.

LIGEZA, A., 2006. Logical Foundations for RuleBased Systems. 2nd edition, Springer, Heildelberg.

LINDSAY, S., 1988. Practical Applications of Expert Systems. John Wiley \& Sons Inc., Chichester.

LOVINS, J.B., 1968. Development of A Stemming Algorithm. Mechanical Translation and Computational Linguistics, vol.11, pp.2231.

MAJUMDER, P., MITRA, M., PARUI, S.K., KOLE, G., MITRA, P. \& DATTA, K., 2007. YASS: Yet Another Suffix Stripper. ACM Transactions on Information Systems (TOIS).

MATHEW, N.V. \& BAI, V.R., 2016. Analyzing the Effectiveness of N-Gram Technique Based Feature Set in a Naive Bayesian Spam Filter. International Conference on Emerging Technological Trends (ICETT).

MAYFIELD, J. \& MCNAMEE, P., 2003. Single NGram Stemming. Proceedings of the 26th Annual International ACM SIGIR Conference on Research and Development in Informaion Retrieval, pp.415-416.

MEMET, R., NIJAT, M., MAHMUT, G. \& HAMDULLA, A., 2017. A Rule and Statistical Modeling Based Stem Extraction Method for Kazakh Words. International Conference on Asian Language Processing (IALP), pp.231-234.

MOULINIER, I., MCCULLOH, J.A. \& LUND, E., 2001. West Group at CLEF 2000: NonEnglish Monolingual Retrieval. CrossLanguage Information Retrieval and Evaluation (CLEF), pp.253-260.

NATA, G.N.. \& YUDIASTRA, P.P., 2017. Stemming Teks Sor-Singgih Bahasa Bali. Konferensi Nasional Sistem dan Informatika, pp.608-612.

NAZIEF, B. \& ADRIANI, M., 1996. Confix Stripping: Approach to Stemming Algorithm for Bahasa Indonesia. Internal
Publication, Faculty of Computer Science, University of Indonesia, Depok.

NIKOLOPOULOS, C., 1997. Expert Systems Introduction to First and Second Generation and Hybrid Knowledge Based Systems. CRC, Boca Raton.

PAICE, C.D., 1994. An Evaluation Method for Stemming Algorithms. Proceedings of the 17th Annual International ACM SIGIR Conference on Research and Development in Informaion Retrieval, pp.42-50.

PATIL, H.B. \& PATIL, A.S., 2017. MarS: A RuleBased Stemmer for Morphologically Rich Language Marathi. International Conference on Computer, Communications and Electronics, pp.580-584.

PORTER, M.F., 1980. An Algorithm for Suffix Stripping. Program, vol.14, pp.130-137.

PORTER, M.F., 2001. Snowball: A Language for Stemming Algorithms.

PRAMUDITA, Y.D., PUTRO, S.S. \& MAKHMUD, N., 2018. Klasifikasi Berita Olahraga menggunakan Metode Naive Bayes dengan Enhanced Confix Stripping Stemmer. Jurnal Teknologi Informasi dan Ilmu Komputer (JTIIK), vol.5, no.3, pp.269-276.

PUTRA, I.B.G.W., SUDARMA, M. \& KUMARA, I.N.S., 2016. Klasifikasi Teks Bahasa Bali dengan Metode Supervised Learning Naive Bayes Classifier. Teknologi Elektro, vol.15, no.2, pp.81-86.

PUTRA, S.J., GUNAWAN, M.N. \& SURYATNO, A., 2018. Tokenization and N-Gram for Indexing Indonesian Translation of the Quran. International Conference on Information and Communication Technology (ICoICT).

SEMBOK, T.M. \& BAKAR, Z.A., 2011. Effectiveness of Stemming and N-Grams String Similarity Matching on Malay Documents. International Journal of Applied Mathematics and Informatics, vol.5, pp.208-215.

TALA, F.Z., 2003. A Study of Stemming Effects on Information Retrieval in Bahasa Indonesia. 